\title{
A INFÂNCIA DO MUNDO. OS PRIMEIROS CONTATOS ENTRE FRANCESES E TUPINAMBÁS NO BRASIL DO SÉCULO XVI*
}

Laurent Olivier ${ }^{1}$

\section{Resumo}

Este texto trata dos primeiros contatos entre franceses e tupinambás no Brasil do século XVI explorando principalmente as reflexões de Jean de Léry sobre a noção de "selvagem" e de encontro e trocas culturais.

\section{Palavras-chave}

Brasil/França; Tupinambás; "selvagens", encontro/trocas culturais

\section{Résumé}

Ce texte discute des premiers contacts entre Français et Tupinambas au Brésil $\mathrm{du}$ XVIe siècle, envisageant surtout les réflexions de Jean de Léry à propos de la notion de "sauvage" et de rencontres et d'échanges culturels.

\section{Mots-clés}

Brésil/France; Tupinambas ; "Sauvages" ; rencontres/échanges culturels.

\footnotetext{
*Tradução do francês por Lettícia Batista Rodrigues Leite - leitele@yahoo.com.br Doutora em História pela Universidade de Paris 1 Panthéon-Sorbonne.

1 Conservador, Musée d'Archéologie Nationale, Saint-Germain-en-Laye, França. E-mail: laurent.olivier@culture.gouv.fr
} 
A terra, a princípio, não é nada senão um aroma indistinto, que certos momentos se insinua no rumor do mar. São notas de um perfume de floresta distante, de frutas maduras e de húmus espesso. Em uma manhã, de repente, ela está lá, insinuando-se pela massa cinza das montanhas que dominam, no horizonte, a superfície do mar. Pode-se pressenti-la imensa, bem maior do que nós. Durante muitos dias e muitas noites, o navio aproxima-se de uma interminável sucessão de costas desertas, onde nenhum fogo brilha na escuridão. Mais de perto, a terra parece abrigada por enormes rochedos que emergem na superfície da floresta que, em certos lugares, parece desembocar diretamente no mar. Até onde a vista alcança, não se distingue o menor traço de ocupação. De tempos em tempos, o horrível silêncio da terra é interrompido pelo eco do grito de macacos e de papagaios. Levados pela imensa massa da embarcação, avança-se em direção a um país virgem de qualquer marca humana, onde os passáros e os animais são abundantes, como nos primórdios do mundo.

Contudo, eles estão lá. A floresta está repleta de milhares de selvagens nus, de terríveis povos canibais, sobre os quais circulam as mais horríveis histórias. É o Brasil. O nosso Brasil perdido, o Brasil das origens. Os huguenotes franceses fundaram ali, em 1555, uma colônia minúscula, sob a autoridade de Nicolas Durand de Villegagnon, vice-almirante da Bretanha. Eles instalaram-se na embocadura do rio Guanabara, em uma ilha que ficaria conhecida pelo nome de Ilha dos Franceses. Duzentos emigrantes são reunidos em um forte batizado de Forte Coligny, em homenagem ao seu protetor, chefe do partido protestante da França. A pequena colônia da "França Antártica" teria uma existência breve, antes de ser destruída pelos portugueses, em $1560^{2}$.

Esse instalação efêmera nos confrontaria com o estranho e com o maravilhoso, com a beleza e com o horror. Ela nos fez conhecer, pela primeira vez, os "selvagens americanos", neste caso, os Toüoupinambaoults ou Tupinambás, uma fração dos povos tupis da baía do Rio de Janeiro, que seria extinta no século XVII. A experiência da alteridade selvagem, proporcionada pela curta presença francesa no Brasil, faria ressurgir uma Antiguidade que nos parecia perdida para sempre. Nós, que jamais havíamos conhecido os povos do Velho Mundo - estrangeiros e no entanto próximos do que éramos -, estávamos de repente confrontados com a dissemelhança absoluta, como outrora o haviam sido os gregos e os romanos, quando do seu avanço aos confins do mundo conhecido. A Antiguidade ressurgiu sob a forma mais inesperada, menos visível: como uma experiência. A experiência do Outro, da sua total proximidade e estranheza, que trouxe consigo a descoberta de uma

\footnotetext{
2 Arrasado pelos portugueses, o Forte Coligny pode ser considerado como o primeiro estabelecimento europeu permanente, que se se encontra na origem da posterior fundação da vila do Rio de Janeiro.
} 
consciência, ainda embrionária, do fim do mundo, suntuoso e frágil, cuja extinção foi diretamente provocada por nós.

\section{Encontro com os "selvagens"}

Dessa história sem amanhã não teria restado nada, ou muito pouco, se um jovem sapateiro da Borgonha, convertido ao protestantismo não tivesse viajado pelo Brasil em 1557. Enviado por Calvino ao Forte Coligny para ali se juntar à comunidade huguenote, Jean de Léry leva de sua estadia na "França Antártica" a narrativa da sua experiência de contato com os Tupinambás, dividido entre sua admiração pela generosidade dos "selvagens" e sua repulsa com relação às suas práticas pagãs ${ }^{3}$. Admirado por Claude Lévi-Strauss, o livro de Léry é a primeira obra de etnografia ameríndia do Brasil. Trata-se, sobretudo, do testemunho de um homem comum, que de repente se vê imerso no universo singular dos "selvagens da América", dos quais, com grande espanto, ele descobre os modos de vida e os códigos de conduta.

Até aquele momento o Novo Mundo era conhecido apenas pelo que se ouvia dizer, por histórias contadas por aquele que dele regressavam. Contava-se que a América era povoada por gigantes de mais de três metros, com duas fileiras de dentes, em cima e em baixo. Alguns diziam que ali habitava um grupo de anões, cuja vida era muito breve e que morriam antes mesmo que nós tenhamos atingido a idade adulta. Outros asseguravam que ali se podia ver homens-macacos, dotados de uma cauda peluda e que lá existiam homens cobertos por pelos tão espessos quantos os dos ursos. É impossível separar a ficção da realidade. Os homens mais respeitáveis espalham as histórias mais inverossímeis, como aquela de bichos com cabeças de criança que se alimentam exclusivamente de vento, dos quais o grande sábio André Thevet, cosmógrafo do rei François I, garante ter possuído um exemplar que teria sido capturado no Brasil (fig. 1) ${ }^{4}$. Portanto, não se pode ter certeza que alguns prodígios não possam de fato ser possíveis, como aquele de homens cujas cabeças encontram-se na região do tórax, ou ainda de seres que se reduzem a um enorme pé, dos quais eles se servem para abrigar-se do sol ardente.

\footnotetext{
${ }^{3}$ Jean de Léry, Histoire d'un voyage faict en la terre du Brésil, autrement dite Amérique. Genève, Antoine Chuppin, 1578. Particularmente popular, a obra terá cinco edições até 1611. Publicada vinte anos depois da viagem de 1557, o livro de Léry é uma resposta à obra publicada, em 1575, pelo católico André Thevet. Em As singularidades da França Antártica, Thevet atribuía aos protestantes a responsabilidade pelo fracasso do estabelecimento francês no Forte Coligny.

4 Trata-se do Haüt, ou Haüthi. André Thevet, Le Brésil d'André Thevet. Singularités de la France antarctique (1557). Paris 1997, éditions Chandeigne, p. 199-200.
} 


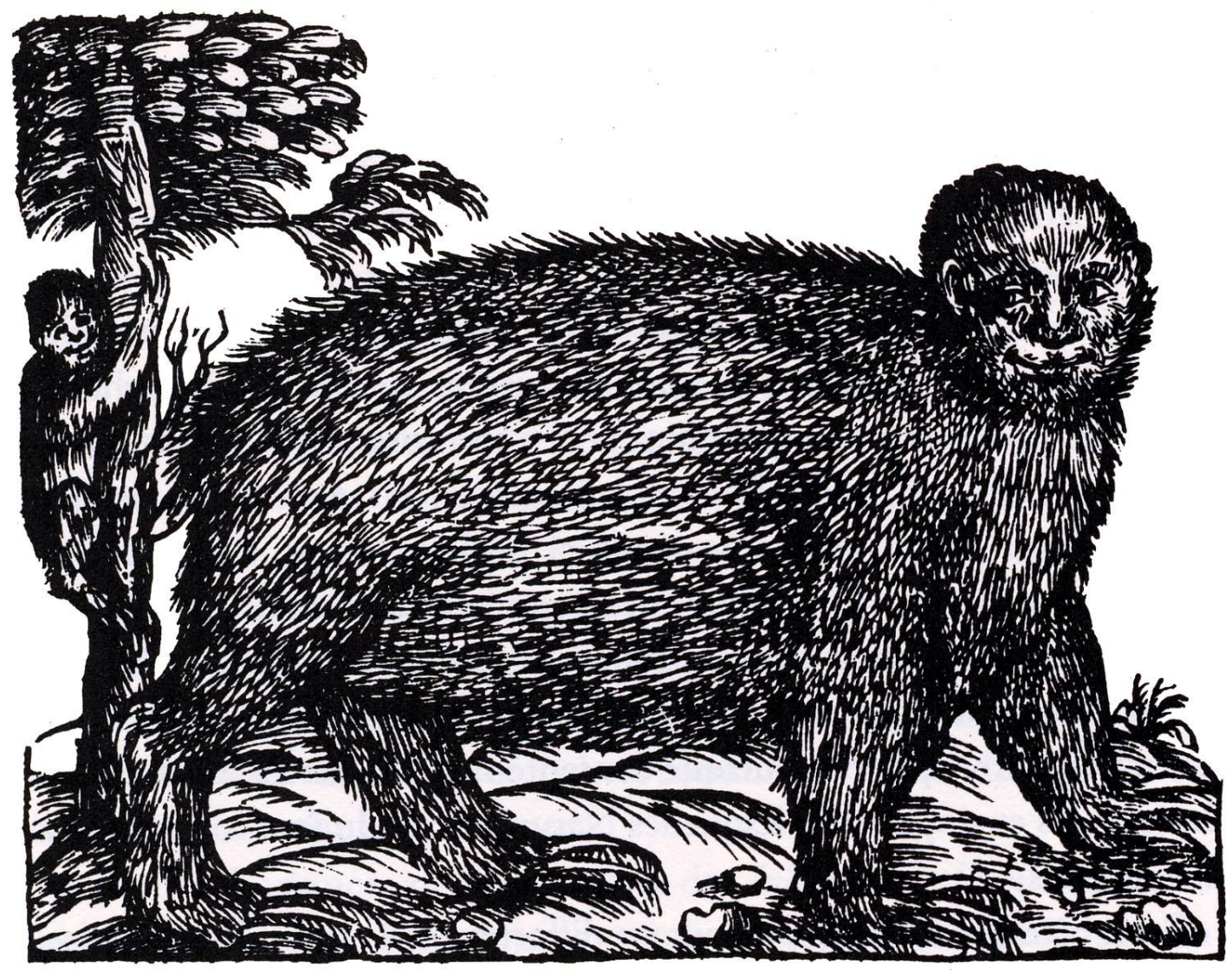

Fig. 1. Haut ou Hauthi - André Thévet. Les singularitez de la France Antarctique, 1557.

Essas quimeras são o produto de uma ascendência particular: elas são oriundas do encontro de velhas fábulas europeias - antes de encontrá-las nas Américas, a maior parte desses prodígios eram projetados na Índia, e antes ainda, nas costas distantes do país dos Citas - com a identidde intangível do mundo indígena. De certa forma, a estranheza do Novo Mundo vem confrontar os europeus antes mesmo que eles a tenham de fato abordado. É por isso que essas ficções são levadas em consideração: elas chegam como sinais que falam na língua do desconhecido. Daquele momento em diante, elas reabilitam as histórias que de bom grado tínhamos como falsas, e que os Antigos haviam trazido de suas viagens ao fim do mundo, assim como Píteas, o inventor da Ultima Thulé, a terra que ficava na extremidade do mundo do gelo $^{5}$. Tendo retornado de sua viagem, Léry fará assim, uma autocrítica, ele escreve: "reconheço que não tenho nenhuma vergonha de confessar que desde que estive nesse país da América (...) desaprovando as fábulas que são lidas nos livros de muitos, as quais se pautam nos relatos que lhes foram feitos, quando não escreviam coisas absolutamente falsas, eu me retratei com relação à opinião que outrora eu tinha de Plínio e de alguns outros que descreveram os países estranhos, porque eu vi coisas igualmente bizarras e espantosas tais

\footnotetext{
5 O geógrafo Etrabão fará, assim, do navegador Píteas "o mais mentiroso dos homens" (Estrabão, Geografia, IV , 3, 5).
} 
como aquelas que aqueles autores fizeram menção, e dentre as quais algumas foram tidas como inacreditáveis 6 .

Não é tanto encontrar um país completamente diferente do deles que causa espanto aos primeiros europeus que aportam no Brasil, mas sim o fato de encontrar seres humanos. Na frente deles, uma multidão de seres nus que se aglomera ao seu encontro, e que também não crê que seja possível que simples homens possam ter vindo do lugar do qual eles vieram, lá, o horizonte onde o céu toca o mar. $\mathrm{O}$ encontro com a humanidade do Novo Mundo resulta de um enorme mal-entendido. Cada um vê o outro, não como de fato ele é - ou tal como ele considera que ele seja -, mas como o que aquele outro representa para si mesmo. E cada um ignora o que representa para o outro que ele não conhece.

Contudo, enquanto ainda não se sabe se o outro é realmente humano - ou mesmo se um dia ele poderia vir a ser - a contaminação começa a operar de modo instantâneo, desde os primeiros contatos, antes mesmo que alguém seja capaz de compreender o outro. No Brasil, os franceses que estiveram famintos ao longo de vários meses no mar fazem sinal, a partir do navio, aos "selvagens" que vêm ao encontro deles. Eles dão a entender que estão dispostos a dar objetos em troca de alimento, mostrando à distância "facas, espelhos, pentes e outras bugigangas" 7 . De pronto é permitido que os ameríndios subam a bordo, uma vez que eles saem de suas canoas com os braços carregados de "farinha feita com uma raiz que os selvagens comem no lugar do pão, presuntos, e de uma certa espécie de javali, com outras comidas e frutas em abundância", tais como o país produz ${ }^{8 \prime}$. Os nossos começam a absorver os alimentos dos "selvagens" e, em breve, eles beberão com avidez o caouin, fumarão com vuluptuosidade o petun ${ }^{9}$ e farão amor com as mulheres deles, que não impõem resistência a acolhê-los. Tendo em vista a impossibilidade de pagar os "selvagens" com dinheiro, eles lhes presenteiam com "camisas, facas, anzóis de pesca, espelhos e diversas mercadorias e produtos". Eles partirão em suas canoas, usando camisas e chapéus franceses.

\footnotetext{
${ }^{6}$ Jean de Léry, Histoire d'un voyage faict en la terre du Brésil (1578). 2ème édition, 1580. Texte établi, présenté et annoté par Frank Lestringant. Paris, 1994, Librairie générale française, p. 28.

7 Léry, op. cit., p. 148.

${ }^{8}$ Léry, op. cit., p. 148.

${ }_{9} \mathrm{Ou}$ kahui em tupi. Trata-se de uma bebida espessa à base de raiz de mandioca moída e fermentada. O viajante alemão Hans Staden a considera "espessa, muito embriagante $e$ nutritiva". Pétun é o nome do tabaco em tupi. Léry, que o provou, considera que a sua fumaça é "satisfatória e evita a fome".
} 


\section{A troca desigual}

Nesse mercado através do qual os objetos europeus são trocados por mercadorias indígenas, o outro, o "selvagem", desconhece o valor representado pelos bens que ele obtém em troca daqueles que ele oferece. A troca é, pois enviesada e, evidentemente, para os europeus é grande a tentação de cometer abusos contra o outro, cuja ignorância ganha para ele ares de estupidez. De fato, desde os primeiros contatos, os recém-chegados se dão conta de que os "selvagens" não compreendem que os que lhes é proposto em troca de seus próprios bens é, na realidade, de pouco valor. O "selvagem", então, dá tudo o que tem e aceita tudo o que lhe é oferecido em troca, ainda que lhe sejam apresentadados restos. Os europeus melhores intencionados interpretam isso como uma espécie de generosidade sem limites, que se explica aos seus olhos pelo fato de que os "selvagens" não dão valor a nada, mesmo ao que eles próprios possuem. É, pois, permitido pegar tudo o que eles têm, presume-se, dado que eles não se importam com isso.

Se os ameríndios dão tudo o que lhes é pedido, é porque dessa maneira eles fazem daqueles que recebem seus aliados e tributários: para eles, à condição de aceitar ser coberto de infâmia, aquele que recebeu deve retribuir o presente que lhe vincula ao outro; sua honra pessoal e a honra do grupo inteiro ao qual ele pertence dependem disso. Para o europeu, a transação termina a partir do momento que a mercadoria troca de mão. Para o ameríndio, ao contrário, ela está apenas começando. Jean de Léry percebeu bem que, para os Tupinambás, o presente tratava-se um modo de troca; ele presumiu, em particular, que o presente tinha a função de consolidar a solidariedade dos indivíduos dentro de um grupo: "Compartilhando e fazendo diariamente presentes uns aos outros, carnes, peixes, frutas e outros bens que eles tinham em seu país", ele escreve, os "selvagens" fizeram sistematicamente uso do dom, pois eles "morreria(m) de vergonha", caso vissem seus semelhantes despossuídos daquilo que eles mesmo tinham, assim como com relação aos "seus aliados estrangeiros." 10

Léry entende essas práticas de dom apenas como atos de "caridade" praticados no interior do círculo da tribo e de seus aliados. Assim sendo, ela caía em uma armadilha bastante recorrente na prática etnográfica, que consite em projetar de forma inconsciente no estrangeiro - nesse caso o "selvagem" do Novo Mundo - os códigos de valores da sua própria cultura; assim, os Tupinambás seriam naturalmente "generosos" e "caridosos", no sentido comum que era dado a esses termos na Europa cristã do século XVI. No começo do século seguinte, o padre capuchinho Yves d'Evreux, enviado para catequizar a ilha do Maranhão, na embocadura do Amazonas, vai

${ }^{10}$ Léry, op. cit., p. 461. 
compreender que, ao contrário das aparências, essas práticas de dom não ignoravam a noção de valor, na medida em que elas consistiam essencialmente em modalidades de troca. Tratava-se, no entanto, de um tipo de valor bem particular que se colocava em questão: para os Tupinambás, o valor do bem cedido encontrava-se no valor que ele realmente tinha para aquele que o possuía, e não, como para os Europeus, no valor que era representado por sua aquisição. Se um dentre eles desejava obter algo que pertencia a um de seus semelhantes, ele escreve, "ele lhe manifestava de forma franca a sua vontade, sendo necessário que a coisa fosse bastante cara àquele que a possui". Em contrapartida, "se o requerente possui algo que o doador aprecia", ele deveria cedê-la "quando aquele solicitar" 11 .

Cerca de três séculos mais tarde, Claude Lévi-Strauss fará com os TupiKawahib do Brasil uma experiência que o relançará na situação descrita no século XVII por Yves d'Evreux. Enquanto lhe é solicitado que ceda a sua grande panela de alumínio, na qual ele prepara diariamente a sua refeição, e que ele multiplica as explicações para justificar a impossibilidade na qual ele se encontra para apartar-se da mesma, ele constata que, quanto mais ele desenvolve a sua argumentação, mais o seu interlocutor Tupi demonstra "um sorriso pleno, como se suas palavras, diz Lévi-Strauss, correspondessem a todos os seus desejos". Quando, afinal, o etnólogo está em vias de concluir a sua argumentação a fim de defender a sua posse, o ameríndio, sem hesitar, toma posse da sua preciosa panela, partindo plenamente satisfeito ${ }^{12}$.

Os homens que chegavam naquela época ao Novo Mundo ainda não distinguiam esses códigos de comportamento, que lhes eram inacessíveis. De fato, europeus e ameríndios não se entendiam no que diz respeito ao estatuto que a troca tinha para o outro e acerca do que consistia o valor dos bens trocados. Para os europeus, era evidente que era possível se servir à vontade dos bens dos "selvagens", até o ponto de tomar posse de todos os seus recursos, dos objetos que eles utilizavam e mesmo dos seres com os quais eles viviam, tendo em vista que eles lhes eram oferecidos de forma espontânea; mas o inverso, claro, lhes era absolutamente inconcebível. Pois, se os ameríndios possuíam coletivamente os bens aos quais eles não pareciam atribuir valor, os europeus estavam certos de tomar posse, individualemente, de bens pessoais, dos quais seria criminoso tomar posse. Assim, seria preciso punir os indígenas que, na perspectiva deles, abusavam de maneira insidiosa da sua confiança, tomando posse de algo que era deles. De modo que, recémdesembarcados, os colonos se sentiam injustiçados e perseguidos, sentimentos

\footnotetext{
11 Yves d'Evreux, Suitte de l'Histoire des choses plus mémorables advenues en Maragnan es années 1613 et 1614. Second traité. Paris 1615, François Huby.

12 Lévi-Strauss, Tristes Tropiques, Paris, éditions Plon, 1955, p. 413-414.
} 
engendrados pela ignorância e pela incompreensão, confundidas com a certeza de que existia um único direito e uma única verdade: a deles.

Colonos e autóctones tampouco eram capazes de se compreender melhor sobre a noção de trabalho. Trabalhar, no sentido entendido pelos europeus, trata-se de uma noção totalmente desconhecida pelos "selvagens". Como foi amplamente demonstrado por Marshall Sahlins sobre as economias ditas primitivas, se os ameríndios não buscam rentabilizar as suas produções, é porque eles não queriam e não porque eles não eram capazes de fazê-lo13. Como os europeus fomentam seus négócios, os ameríndios que eles encontram lhes transmitem a imagem de populações ociosas, que passam o tempo dançando e a "cahouiner", quer dizer a se embrigar, isso quando ele não estão empenhados em uma guerra. Ninguém se dá conta do fato de que não lhes falta nada. Em particular, ninguém enxerga o trabalho feito pelas mulheres que, quando não estão tomando conta das crianças e da casa, cultivam a terra, ocupam-se das colheitas ou, ainda, fabricam os potes e a maior parte do objetos domésticos.

Aos olhos dos europeus, os "selvagens", que foram colocados para trabalhar na exploração do pau-brasil, ignoram a noção de trabalho, na medida em que eles não tem a menor ideia do valor representado por ele. Para os europeus que os exploram, os "selvagens" lhes ajudam de maneira espontânea, em troca de bens de pouco valor que lhes satisfazem. Na melhor das hipóteses eles são tidos como seres inocentes e predispostos, que podem ser empregados no trabalho braçal, pois isso não lhes afeta. Na pior, trata-se de preguiçosos corrompidos, que devem ser educados e corrigidos. Sendo assim, é justo de forçá-los trabalhar, já que isso não representa nada para eles. Além disso, quando eles se queixam, não vale a pena submetê-los a constrangimentos, basta que o sistema de trabalho imposto pelos europeus os prive dos prisioneiros de guerra, quer dizer, de uma reserva de vítimas suficientes para perpetuar o canibalismo ritual ${ }^{14}$. De que serve ter a escrúpulos, tendo em vista que, nessas condições, o trabalho representa para eles apenas um progresso benéfico que os mantêm afastados de práticas repugnantes?

\section{O esgotamento do Novo Mundo}

Um sistema produtor de desigualdades, nascido da colisão de modos de troca inconciliáveis, propospera no Novo Mundo. O sistema de traição, que é

\footnotetext{
13 Marshall Sahlins, Age de pierre, âge d'abondance. L'économie des sociétés primitives. Traduction française de Tina Jolas. Paris 1972, éditions Gallimard, collection Bibliothèque des Sciences humaines.
}

14 Léry, op. cit., p. 353.

Heródoto, Unifesp, Guarulhos, v. 3, n. 1, Março, 2018. p. 538-562 
instaurado desde os primeiros contatos, deixa uma profunda impressão de injustiça. Pois, enquanto os europeus vão e vêm abarrotados de "presentes" continuamente feitos pelos "selvagens", estes obtêm apenas objetos insignificantes, isso quando não são completamente despojados por aqueles. "Muitos dentre nós, narra Léry, partíamos cheios de objetos pessoais que eles (os Tupinambás) nos haviam dado e que eram transportados nas redes onde eles dormiam: penas esplêndidas, arcos e flechas em grande quantidade, assim como uma infinidade de papagaios de cores variadas".

Até o momento em que as instalações europeias no Novo Mundo se tornassem suficientemente autônomas, foram os ameríndios que, além de tudo, forneceram alimento aos homens recém-desembarcados dos navios. Neste mundo tão diferentes do deles, os europeus eram incapazes de produzir algo para manter a sua própria subsitência. São sobretudo os ameríndios que, de imediato são usados a serviço deles. Do Brasil, os franceses levam essencialemente madeira de cor, algodão e pimenta, assim como papagaios e pequenos macacos oferecidos pelos Tupinambás ${ }^{15}$. Eles os obtêm em troca de tecidos coloridos baratos, com os quais os navios são carregados ao partir da França e são usados para confeccionar roupas para os indígenas ${ }^{16}$.

Contudo, desde o momento em que são transportados para a Europa, esses materiais ou esses animais adquiridos a baixo custo convertem-se em bens de luxo particularmente apreciados. Assim, desde a origem da transação com os ameríndios, a troca é enviesada, pois ela é pautada na permuta de bens que estão longe de ser equivalentes. O "selvagem" oferece, basicamente, recursos naturais cuja obtenção lhe custa um tempo de trabalho considerável. Os homens devem abater as aramboutan, árvores por vezes gigantescas, que fornecem o pau-brasil; eles devem retirar os troncos e transportá-los nas costas até os barcos, percorrendo distâncias que às vezes perfazem uma quinzena de quilômetros. Além disso, eles têm que caçar de forma intensa os papagaios ou os macacos. As mulheres, por sua vez, devem passar longas horas colhendo o algodão e a pimenta, ou ainda colhendo e preparando os ingredientes da comida que será oferecida aos europeus... Em contrapartida a esses produtos, cuja exploração exaure o seu meio ambiente, os Tupinambás recebem bens manufaturados que não são necessariamente indispensáveis para os europeus, ou cuja aquisição, em todo caso, não thes custou nennhum esforço pessoal, tendo em vista que eles apenas compraram estoques de tecidos, caixas de

\footnotetext{
${ }_{15}$ Hans Staden, Nus, féroces et anthropophages (Marburg, 1557). Traduction française d'Henri Ternaux-Compans. Paris 1979, éditions A.-M. Métaillé.

16 Como Léry aponta, "tendo levado em seus navios uma grande quantidade de frisos vermelhos, verdes, amarelos e de outras cores, nós os obrigávamos a fazer vestidos e calções multicoloridos, que trocávamos por víveres, guenons, papagaios, pau-brasil, algodão pimenta-longa, e outras coisas do país, com as quais os marinheiros carregavam normalmente os seus navios." (Léry, op. cit., p. 226).
} 
ferramentas, ou sacos com pequenas peças de vidro, que lhes proporcionaram um benefício incomparável com relação ao investimento feito ${ }^{17}$.

O considerável volume de bens extraídos do país dos Tupinambás causa espanto. Em 1531, a fragata La Pélerine, por exemplo, levava um carregamento de aproximadamente 3000 peles de leopardo, 300 macacos e guenons e 600 papagaios "que já sabiam algumas palavras de francês". ${ }^{18}$ No espaço de tempo de quase algumas décadas, a presença europeia conduz, de forma irremediável, a uma superexploração do meio ambiente florestal ameríndio, que rapidamente assiste ao esgotamento dos seus recursos, em essência limitados. Levando à escassez dos recursos ao mesmo tempo em que aumentava a pressão imposta ao meio, a exploração colonial do Brasil não apenas desestabilizava o meio ambiente como também desestruturava as comunidades indígenas. A superexploração do meio, de fato, ampliava os conflitos entre as etnias que, a partir daquele momento, passavam a competir pela obtenção dos recursos que eram procurados pelos europeus. Essas guerras tribais eram exarcebadas pela rivalidade entre os franceses e os portugueses, que se tornavam aliados das tribos inimigas, às quais eles fornecem armas de fogo cujo poder de destruição era incomparável com relação àquele dos armamentos tradicionais dos ameríndios. Um mecanismo de desintegração, ao mesmo tempo ambiental e cultural era, pois, desencadeado pela presença dos europeus no Novo Mundo.

No momento em que começam a ser conhecidas - em meados do séculos XVI -, as populações ameríndias do Brasil não são ainda, de fato, desaculturadas. Antes de serem submetidas à dependência cultural - prelúdio do seu desaparecimento -, os europeus, a princípio, submetem-nas a uma dependência econômica, tendo em vista que, de agora em diante, os ameríndios precisavam de ferramentas de metal que eral fornecidos pelos brancos, para que, de um ponto de vista econômico, pudessem sobreviver na nova economia de mercado. $\mathrm{O}$ esgotamento do meio ambiente, as guerras devastadoras, os novos jogos do poder levariam, em breve, à ruptura os quadros tradicionais daquelas sociedades. Com o antropólogo Pierre Clastres demonstrou, a estrutura dessas sociedades de caçadores-coletores da América do Sul visava garantir a perenidade dos grupos humanos em um meio ambiente natural e com recursos limitados. Ela se opõe, em especial, à acumulação de mais valia econômicas e ao desenvolvimento demográfico das populações - tendo em vista que ambas introduziriam o risco de um esgotamento irreversível do meio -, que mantém, especialmente por

17 "Deixo-lhes refletir a que preço (esse trabalho feito pelos ameríndios) e era pela sede de ganhar algum pobre traje com forro rude ou alguma camisa", escreve Thevet (op. cit., p 227).

18 Lévi-Strauss, op. cit., p. 91. 
intermédio das guerras tribais, uma fragmentação máxima das comunidades ${ }^{19}$. Ou seja, essas sociedades buscavam impedir justamente o que era provocado pela instalação de colonos vindos da Europa. A guerra, que era reguladora, tornara-se destruidora neste novo ambiente criado pelos europeus.

\section{Seja gentil, francês, dê-me uma pulseira de pérolas}

Na proximidade do rio, uma bala de canhão, cujo eco vai se perder na imensidão da floresta, é disparada a partir de um navio. Os "selvagens" saem aos poucos das cabanas e se reúnem nas margens do rio. Os europeus desembarcam baús repletos de mercadorias enquanto aqueles levam comida. Trocas são feitas. Discute-se e, aos poucos, cada um passa a aprender a linguagem do outro.

- “Ere-ioubé? Você veio?

- Pa-aiout. Sim, eu vim.

- Teh! auge-ny-po. Bem dito. Ere-iacasso pienc? Você deixou o seu país para vir instalarse aqui?

- Pa. Sim.

- Erérou dé caramémo? Você trouxe seus baús?

- Pà arout. Sim, eu os trouxe.

- Mobouy? Quantos são?

- Mocouein. Muitos.

- Maé pérérout, de caramémo poupé? O que você trouxe nesses baús?

- A-aub. Roupas.

- Mara vaé? De quais cores?

- Sobouy-eté. Há azuis. Pirenc. Vermelhas. Ioup. Amarelas. Tin. Brancas. ${ }^{20}$

- Maé pamo? E o que mais?

- A cang aubé-roupé. Trouxe chapéus.

- Seta-pé? Há muitos?

- Icatouvapé. Mais do que você seria capaz de contar.

- Ai pogno? E é tudo?

- Erimen. Não.

- Esse non bat. Então me mostre.

- Coromo. Espere um pouco.

- Neîn. Pois não; diga-me.

- Bem: Mororocap. Tenho arcabuzes. Mocap-couiourou. E também cornos de pólvora.

- Mâe pè sepouyt rem? O que você vai querer em troca deles?

- Arouri. Nada; Eu apenas os trouxe comigo.

- Hé! Vamos!

- Karamoussee. Em uma outra oportunidade.

- Tâcepiah taugé. Eu gostaria de adquiri-los agora.

- Arrou-ita ygapen. Eu também trouxe espadas de ferro...

19 Pierre Clastres, La société contre l'État. Recherches d'anthropologie politique. Paris 1974, éditions de Minuit.

20 Isto é, camisas. 
- Nacepiac-icho péné? Eu posso vê-las?

- Bégoé irem. Outro dia. Eémbereinguè. Espere um pouco.

- Néréroùpe guya-pat? E foices, Você trouxe?

- Arrout. Sim.

- Igatou-pé? Elas são bonitas?

- Guiapar-été. Elas são excelentes.

- Ereroupè itaxé amo? Você não trouxe facas?

- Arroureta. Tenho muitas.

- Maé pamo? E o que mais?

- Pinda. Tenho anzóis. Montemonton. Passadores. Arroua. Espelhos. Kuap. Pentes.

Moùrobouy été. Colares ou pulseiras de vidro azul. Cepiah yponyéum. Como esses, você nunca viu; são os mais belos até então trazidos aqui.

- Easo ia-voh de caramemo t'acepiah dè maè. Abra seu baú, quero ver o que tem dentro.

- Aimossaénen. Não posso.

- Nârour icho p'Irèmmaè desve? E você, o que você quer receber?

- Mae! Pereou potat? O que você pode me dar?

- Sceh dè; maé péréi potat? Não sei; o que você quer?

- Pira, Queria peixe. Ouy, farinha. Commenda-ouassou, grandes favas. Commenda-miri, pequenas favas. Morgouia ouassou, laranjas e limões. Maé tirouèn, todo tipo de coisa diferente.

- Che-rorup-gatou, derour-ari. Eu estou muito feliz que você tenha vindo. Nère roupé d'eré miceco ? Diga-me, por que você não trouxe a sua mulher?

- Arrout iran-hèreco augernie. Eu a trarei quando eu tiver acabado os meu negócios.

- Ty ierobah apoau ai. Correspondamos à glória do mundo que nos procura." 21

Na terra firme, as mulheres e as meninas tomavam o braço dos estrangeiros vindos do mar e lhes diziam: "Mair, deogatorem, anabé mauroubi"; quer dizer: "Seja gentil, francês, dê-me por favor uma pulseira de pérolas". Com as pérolas de vidro azul que lhes seriam dadas, elas fariam enfeites que substituiriam aqueles que elas fabricavam tradicionalmente com conchas. Onde quer que eles fossem, os franceses eram seguidos por bandos de crianças, que repetiam aos risos o que eles diziam: "Contoüassat, amabé pinda"; o que quer dizer: "Meu amigo e meu aliado, dê-me anzóis para a pesca" 22. Eles utlizariam esses acessórios de ferro, que substituiriam aqueles que até então eram talhados em ouro ou em madrepérola. Assim, a tecnologia dos Tupinambás seria rapidamente transformada pelas ferramentas de ferro que eram trazidas pelos franceses. Para cortar e fatiar o pau-brasil, daquele momento em diante, os ameríndios serviam-se de machados e de pedaços de ferro no lugar de seus utensílios tradicionais de pedra. Mas, cada vez mais, eles empregam também instrumentos de ferro para realizar os seus produtos tradicionais de ornamentos de pluma. Assim, os Tupinambás de meados do século XVI ainda fabricavam os mesmo tipos de objeto, com os mesmos tipos de ornamentos tradicionais do passado, mas que, a partir daquele momento,

${ }^{21}$ Léry, op. cit., p. 479-489. A obra Léry traz um primeiro dicionário de termos da língua dos Tupinambás e um guia das expressões utilizadas no momento das trocas.

22 Léry, op. cit., p. 231, 233. 
passavam a ser elaborados como outros utensílios - os europeus - produzindo produtos efetivamente mestiços.

Nesse sentido, a introdução do ferro nessas populações de caçadores-coletores do Brasil ultrapassa a imagem de um simples fenômeno de importação, na medida em que ela introduzia, na fabricação dos objetos da cultura material tradicional, o aparecimento de produções híbridas, metade indígenas e metade estrangeiras. Os objetos importados eram eles mesmos adaptados, quer dizer "traduzidos" no seu meio receptor Tupi. Léry percebeu assim que, os Tupinambás pegavam as facas de ferro que lhes eram oferecidas, mas jogavam fora as suas capas, visto que não lhe atribuíam utilidade alguma. Além disso, é bastante verossímel que os tecidos coloridos levados pelos europeus - e sobretudo os "calções coloridos" evocados por Léry - tenham sido adotados pelos ameríndios do Brasil graças às suas cores vivas que lembravam os vermelhos, os azuis e os amarelos radiantes das suas roupas de plumas tradicionais.

Na verdade, esses fenômenos de adaptação e de apropriação de elementos da cultura material estrangeira funcionavam em duplo sentido. Os europeus, que tentavam recriar no Novo Mundo o universo material deixado do outro lado do oceano, encontravam-se objetivamente imersos na cultura material ameríndia. Na minúscula França antártica, eles dispunham apenas de alimentos indígenas - como da farinha de mandioca, do peixe "boucané" e "de outras raízes cozidas na brasa" 23 -, comida com a qual eles acabaram por se acostumar 24. Em seu dia a dia, os colonos usavam igualmente acessórios ameríndios, que daquele momento em diante substituíam aqueles que lhes eram indispensáveis na Europa. Quando Jean de Léry e seus companheiros se instalam, por exemplo, para a primeira noite deles nas cabanas desprotegidas do vento do Forte de Coligny, eles dispunham apenas de redes tupinambás como leito: naquela noite, ele escreve: "como os americanos, nós penduramos os lençois e as camas de algodão para deitarmos ao ar livre" ${ }^{25}$

No Novo Mundo, os europeus que haviam desembarcado dos seus navios estavam ávidos por tudo: primeiro por comida, mas sobretudo por informações. As pessoas daqui já haviam visto homens semelhantes a eles? Eles conheciam outros rios, outras terras, outros povos? Ficavam longe daqui, por onde podia-se chegar lá? Eles saberiam se era possível encontrar ouro por aqui? Quem entre eles detinha a sua posse? As primeiras palavras trocadas entre as línguas eram aquelas que serviam para perguntar: como se chama

\footnotetext{
${ }^{23}$ Léry, op. cit., p. 164.

${ }^{24}$ Léry conta assim que, ao retornar à França, alguns dos seus companheiros tinham "tomado tanta aversão ao vinho, que eles ficaram mais de uma mês sem sequer poder sentir o seu cheiro e ainda menos prová-lo. (Léry, op. cit., p. 547)
}

${ }^{25}$ Léry, op. cit., p. 164. 
esse objeto, esse utensílio? Qual o nome desse alimento? As novas palavras que surgiam eram aquelas que davam nomes às coisas, as quais era preciso conhecer para obter do outro o que se havia vindo procurar desde tão longe. À força de serem repetidas, essas palavras se inseriam na linguagem, adaptandose a ela. Sob o impacto de termos vindos do outro lado do mundo, o vocabulário acabava por se crioulizar. Algumas das antigas palavras americanas são introduzidas na língua francesa: os Tupinambás do Brasil nos deram topinambours, manioc, goyave, cajou, ananas... Mas quem ainda se recorda que o termo caribe, dado às primeiras populações encontradas por Colombo, é derivado do fato de que elas tinham por costume acolher os estrangeiros com a palavra "Caraiubé", que na língua daqueles povos significava "vida boa" ou "sejam bem-vindos"? 26

\section{"Animais com rosto humano"}

As suntuosas imagens que compunham As Grandes viagens de Théodore de Bry nos mostram os "selvagens da América" com a aparência de gigantes nus, evocando as figuras dos deuses da Antiguidade, mas armados com arco e com maças de madeira. Esses guerreiros selvagens apareciam diante das embarcações europeias em um grande número de canoas, usando enfeites de plumas de cores vívidas: coroas insólitas ou penteados com plumas verticais, e ornamentos com plumas irradiantes presas por um laço amarrado a tiracolo, que os guerreiros usavam na lombar ${ }^{27}$. Para as danças cerimoniais que eram realizadas em grupo, eles se enfeitavam com capas de plumas e com colares de plumas amarradas na panturilha. $\mathrm{O}$ corpo deles era recoberto com uma fina penugem de pluma pintada de vermelho com pau-brasil, desenhando a pele com marcas de cores vivas. A parte frontal do crânio era raspada, assim como a parte detrás da cabeça e o alto da nuca. O corpo deles, frequentemente pintado em preto, era completamente depilado.

O lábio inferior dos homens era perfurado: os adolescentes, indica Léry, usam um pequeno ornamento de osso polido em forma de quilha que, quando eles se tornavam adultos, era substituído por uma grande pedra verde"com diâmetro e largura duas vezes maior do que um tostão $28 "$. Em volta do pescoço os homens trazem "meias-luas mais longas que meio pé, feitos com ossos bem unidos, tão brancos como o alabastro, ao qual eles dão o nome de Y-

\footnotetext{
26 Thevet, op. cit., p. 113.

${ }^{27}$ Esses "penachos" são chamados Araroye em tupi. Léry, op. cit., p 223. Théodore de Bry, Le Théâtre du Nouveau-Monde. Les Grands Voyages de Théodore de Bry. Présenté par Marc Bouyer et Jean-Paul Duviols. Paris 1992, éditions Gallimard, collection Découvertes Gallimard Albums. ${ }^{28}$ Léry, op. cit., p. 216.
} 
aci, que deriva do nome da lua, que eles chamam assim"29, assim como colares de discos com conchas polidas, chamados Boüre. A vestimenta das mulheres parecia sempre mais discreta se comparada à pompa dos guerreiros. Elas não usam mais do que, eventualmente, um colar com pequenas conchas. Seus longos cabelos pretos eram enrolados em tranças e amarrados com fios de algodão de cor vermelha. Sobre os ombros, elas por vezes traziam tiras estreitas, nas quais elas carregavam as crianças nas costas (fig. 2).

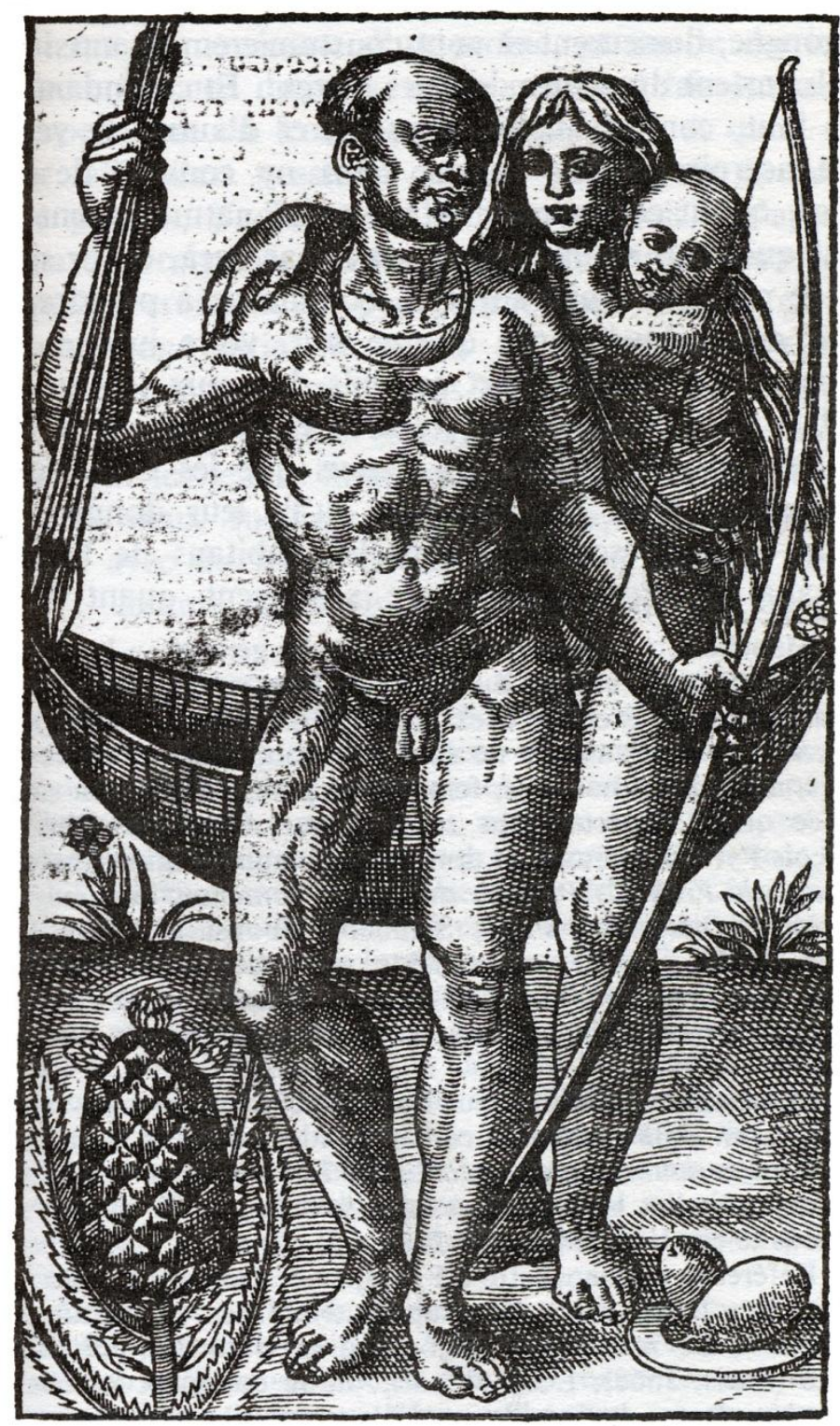

Fig. 2. Família de índios do Brasil, século XVI. LERY, Jean de. Histoire d'un voyage fait en la terre du Brésil, Autrement dite Amérique, 1578.

Por todas as partes que eles os encontram, os europeus ficam primeiramente chocados diante nudez dos "selvagens" do Novo Mundo, que lhes era exposta sem reservas. O contato com o corpo nu dos ameríndios fora talvez mais

${ }^{29}$ Léry, op. cit., p. 219.

Heródoto, Unifesp, Guarulhos, v. 3, n. 1, Março, 2018. p. 538-562 
intenso no Brasil, onde todo europeu quase que de imediato se perderia na floresta, caso ele tirasse, ainda que por um instante, os olhos das costas nuas dos homens indígenas que os precediam em guia, ou mesmo que os levavam nas costas como crianças pequenas. Apesar dos quatro séculos que as separam, as gravuras de As Grandes viagens de Théodore de Bry e as fotografias em preto e branco, reunidas por Lévi-Strauss no seu Tristes trópicos, trazem a marca do mesmo fascínio pela nudez ameríndia. Nessas imagens, pode-se ver os homens de costas, reunidos para dançar, solidamente dispostos sobre suas pernas e usando trajes estranhos e belos, com longas plumas de cores vibrantes. As mulheres estão completamente nuas. É possível observá-las conversando entre si, deitadas de forma distraída nas redes, ou adormecidas sobre o chão, como na Europa apenas os animais, os mendigos e os ébrios o faziam. Desde o século XVI, os europeus, envoltos em suas vestimentas, eram tentados pelos corpos das mulheres ameríndias abandonas aos seus olhares. Tal como Lévi-Strauss por intermédio do seu aparelho fotográfico, eles contemplavam-nas nuas enquanto elas dormiam, deitadas sobre esteiras ou diretamente na terra vermelha, em meio aos escombros de cascas, às vezes com uma pequena criança enlaçada, posando suas delicadas mãos nos seu seios (fig. 3). Dos corpos dessas mulheres e dessas meninas selvagens emanava uma expressão de liberdade iconcebível, para não dizer insuportávél. Tratavase de uma liberdade que não se podia saber se era admirável ou vil.

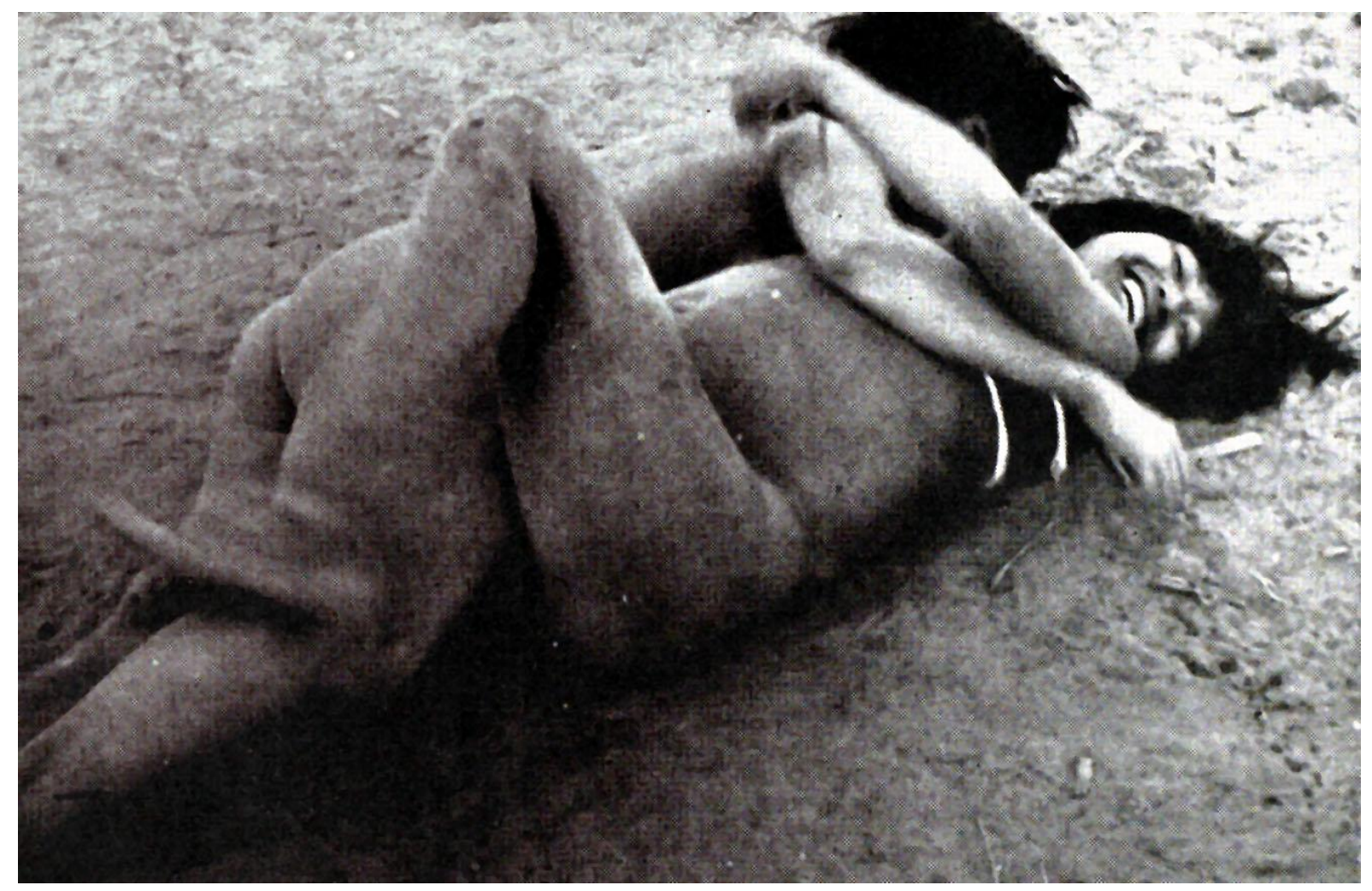

Fig. 3. “Dois". Claude Lévi-Strauss. Saudades do Brasil, 1994. 
Pois, logo após uma cabana, a beleza pode, em um instante, transformar-se em horror: entre eles, os "selvagens" consomiam carne humana. As ilustrações de Théodore de Bry, que estampam os episódios da estadia forçada de Hans Staden, prisoneiro durante longos meses dos ameríndios do Brasil, apresentam a antropofagia como o centro da atividade social dos "selvagens". Todas as etapas do processo de devoração do homem encontram-se representadas ali, em detalhes, desde o abate das vítimas, passando pela preparo do corpo, por seu corte, cozimento das partes e, por fim, pelo seu consumo coletivo. São as mulheres, belas e nuas, que são retratadas preparando os corpos das vítimas evidentemente masculinos - e levando os pedaços para serem cozidos. Os guerreiros matam e cortam. Nos desenhos mais incríveis de Théodore de Bry, uma assembleia de "mulheres selvagens" se reúne: elas são representadas agachadas em torno dos pratos (?) sobre os quais encontram-se dispostas, de forma bem evidenciada, a cabeça de um homem cortada e as vísceras. Uma dentre as mulheres do grupo, que traz uma pequena criança nas costas, servese com avidez. Essa assembleia de ogras deleita-se com esses miúdos dificilmente identificáveis, que elas compartilham com suas crianças. Mulheres e crianças levam às suas bocas pedaços que contêm, segundo de Bry, "uma espécie de caldo (de carne humana) chamado mingau".

Essas perturbadoras gravuras, feitas a partir das informações de Staden, mostravam ao público europeu uma indescritível selvageria dos homens do Novo Mundo. Elas visam restituir, da forma mais precisa, a verdade. Não se trata mais, aqui, de histórias de monstros fabulosos, mas de uma situação autêntica, atestada por testemunhas fidedignas que assistiram com seus próprios olhos. Conforme narra o próprio Staden:

As mulheres tomam as vísceras, colocam-nas para cozinhar, e preparam uma espécie de caldo chamado mingau, que elas compartilham com as suas crianças: elas devoram também as vísceras, a carne da cabeça, o cérebro e a língua; as crianças comem o resto. Logo tudo chega ao fim, cada um pega o seu pedaço e volta para casa. Eu vi e assisti a todas essas cerimônias." 30

O paraíso do Novo Mundo revela-se, na realidade, um inferno. Uma gravura de As Grandes viagens de Théodore de Bry representa a viagem de Léry ao Brasil. O olhar domina a cena, no primeiro plano vemos Léry e um de seus companheiros tentando persuadir um "selvagem" nu a renunciar às suas horríveis práticas pagãs: com o Index levado em direção ao céu, o protestante indica o lugar ocupado por Deus, a quem todos os homens da terra devem fé e obediência. O homem que o acompanha dá de ombros, sua mão é levada ao rosto, ele considera com horror o espetáculo de desolação que tem lugar atrás dos dois homens, em terra brasileira. Esse mundo é maldito: demônios que fazem caretas e quem possuem garras e chifres, tomam os "selvagens" de

30 O testemunho de Staden é publicado em 1557, em Marbourg (Hans Staden, op. cit.). 
assalto enquanto eles dormem e os perseguem para castigá-los. No céu voam rudemente monstros com corpo de serpente ou com asas de vampiros. Ali bem perto, o mar, onde se encontra um navio europeu, está infestado de peixes enormes e assustadores. No plano de fundo, concentram-se as pobres cabanas dos Tupinambás, feitas com madeira e folhas, mergulhadas nesse universo de tormentas. Ao contrário dos europeus, que são protegidos pela fé em Deus, os "selvagens" estão entregues aos demônios pela sua bestialidade indecorosa. O Novo Mundo é um país selvagem, logo diabólico. E os homens que povoam essa terra de perdição não se tratam de homens, mas de seres que possuem apenas uma aparência física supercial humana em comum com a verdadeira humanidade, a europeia. Villegagnon, o despótico criador da colônia huguenote do Forte de Coligny, já dissera sobre os ameríndios brasileiros que ele havia encontrado: (são) "pessoas indômitas e selvagens, distantes de qualquer humanidade, completamente diferentes de nossos modos e cultura: sem religião, e sem conhecimento acerca da honestidade e da virtude, sobre o que é justo e injusto". E afirmava ainda: "de sorte que eu me perguntava se havíamos encontrado animais com aparência humana"31.

\section{Repelir o enselvajamento}

Monstros bestiais escondidos sob uma aparência humana: assim eram, para os franceses, os "selvagens" do Novo Mundo. Aos olhos deles, era essencial evitar, o tanto quanto fosse possível, relacionar-se com aqueles seres desprovidos de toda ideia de moral. O que era ainda mais necessário, tendo em vista que a "selvageria" tende, de forma insidiosa, a ganhar o mundo todo. Começa-se por adotar o modo de vida dos "selvagens" - a se acostumar com a comida deles, dormir como eles em redes... - e depois, sem dar-se conta, a comprometer-se com eles. Léry denuncia, assim, o comportamento de franceses que se relacionam com os "malditos" indígenas, manifestamente numerosos às margens da pequena instalação francesa ${ }^{32}$. A manutenção de uma ausência de coexistência com os "selvagens" era considerada como vital para a conservação da integridade da comunidade de origem francesa, a tal ponto que, no Forte Coligny, Villegagnon punia com morte todo cristão que fosse morar com uma mulher indígena.

Contudo, alguns entre os franceses expatriados, chegaram ao ponto de preferir a vida livre levada pelos "selvagens" na floresta à existência miserável a qual

${ }^{31}$ Léry, op. cit., p. 69. Thevet ele mesmo afirma que os ameríndios do Brasil eram "pessoas extraordinariamente estranhas e selvagens, sem fé, sem lei, sem religião, sem qualquer civilidade, que viviam como animais irracionais, tal como a natureza lhes havia feito, comendo raizes, estando sempre nus, tanto os homens quanto as mulheres..." (Thevet, op. cit., p. 122)

32 Léry, op. cit., p. 180 e 71. 
eles estavam condenados no simulacro de civilização do Forte Coligny. Eles não tardariam a abandonar a comunidade dividida dos colonos, para integrar as comunidades indígenas. Nesse sentido, Léry relata que um grupo de homens da pequena colônia francesa, não suportando mais os péssimos tratamentos aos quais Villegagnon os submetia, fugiram pela floresta para ir ao encontro dos "selvagens". Eles "preferiram, escreveu Léry sobre esses fugitivos "sendo mais maltratados que nas galés", partir em direção à terra firme com os selvagens (os quais, além do mais, tratavam-nos de maneira mais humana) a permanecer com Villegagnon"33. Em outra parte, havia um grupo de marinheiros normandos, sobreviventes de um naufrágio, que há muito tempo haviam se estabelecido entre os Tupinambás, onde se casaram e fundaram famílias. Ali, diz Léry, "vivendo sem temer a Deus, eles mantinham relações luxuriosas com mulheres e meninas (como eu vi, alguns já tinham filhos entre quatro e cinco anos)." 34

Grupos de europeus estabeleceram-se, pois, deliberadamente, entre os "selvagens", de onde eles decidiam nunca mais partir. Entre eles se encontravam, igualmente, os "intérpretes"; quer dizer, jovens que, orfãos ou abandonados, foram enviados às comunidades Tupinambás, quando ainda eram crianças, para aprender a linguagem daqueles povos - de alguma forma como uma segunda língua materna - para que, assim, pudessem servir de intérpretes junto aos franceses. Quando Léry vem ao Brasil, os "intérpretes" que ele encontra estão aqui estabelecidos, em alguns casos, há cerca de nove ou dez anos. ${ }^{35}$ Uma vez adultos, muitos dentre eles já haviam vivido mais tempo na floresta brasileira que em contato com a civilização, que havia se tornado apenas uma lembrança remota pertencente à pequena infância. Eles haviam se "enselvajado", tornando-se, em sua maioria, Tupinambás de pele branca. Léry cita os casos de vários "intérpretes" originários da Normandia, instalados nas comunidades Tupinambás há cerca de oito ou nove anos, os quais, ele diz,

levavam uma vida de ateu, tendo não apenas se maculado com toda sorte de luxúrias e vilanias entre as mulheres e as meninas - dentre as quais algumas tinham um filho com cerca de três anos; como chegado a ultrapassar os selvagens em termos de desumanidade. Soube que alguns se gabavam de ter matado e comido prisioneiros. ${ }^{36}$

Nesse discurso de denúncia do enselvajamento, são as mulheres indígenas que claramente são designadas como responsáveis pela perda dos europeus: elas são nada mais do que "malditas", que lhes atraem sexualmente e, em pouco tempo, engravidam, a fim de envolvê-los, cada vez mais, em uma vida de

\footnotetext{
${ }^{33}$ Léry, op. cit., p. 189.

${ }^{34}$ Léry, op. cit., p. 180.

35 Léry, op. cit., p. 79.

${ }^{36}$ Léry, op. cit., p. 370.
} 
depravação que lhes levará a negar a fé. Pois, como lembra Léry, eram as mulheres indígenas que rejeitavam as roupas que lhes eram dadas para escoder a nudez e que se exibiam completamente nuas à noite, quando elas retornavam à selvageria impudica ${ }^{37}$. Aos olhos de quelquer bom cristão, as mulheres indígenas eram más, porque irredutivelmente selvagens e por ameaçar, por intermédio do simples contato, a integridade moral dos homens civilizados.

Assim, um racismo dirigido contra os "selvagens" prosperava no interior da pequena colônia de expatriados estabelecidos na França Antártica. Esse racimo "antiselvagem", expresso sobretudo pelos franceses, desenvolvera-se desde o momento em que se estabelecera uma relação de dominação com relação aos ameríndios, em particular a partir do momento em que fora instaurado um sistema de exploração de recursos da floresta brasileira, efetuado pelos ameríndios em benefício dos europeus. Daquele momento em diante, as particularidades culturais daqueles povos (como viver nu, trocar bens no quadro de uma economia do dom, praticar a antropofagia, não crer em Deus, etc...) passavam a ser consideradas como práticas desviantes, que deveriam se incessantemente reprimidas e que, em todo caso, permitiam lhes identificar como seres não civilizados. Nessa configuração, ou os "selvagens" do Novo Mundo eram assimilados, e nesse caso eles estavam destinados a tornar-se cristãos de segunda classe; ou esses seres desviantes não seriam assimilados e, nesse caso, seriam considerados como nada mais que uma forma de humanidade inferior: uma espécie que, para o bem da verdadeira humanidade - a saber, a europeia - precisava ser imperativamente aniquilada.

\section{Como é possível ser selvagem?}

Mas, quem são, de fato, esse "selvagens americanos"? É possível conhecê-los para além da sua imediata aparência de estranheza e, nesse caso, o que dizer a respeito? Nada é menos certo, e os observadores que conviveram com eles durante um tempo suficiente a ponto de que eles se tornassem familiares, confessam a sua impotência, tal como o faria primeiro Léry: "Devido a seus gestos e comportamentos totalmente distintos dos nossos, confesso, ele escreve, que tenho dificuldades para representá-los bem, seja por escrito, seja pela pintura. ${ }^{38}$ " Aparentemente, nada do que conhecemos nas nossas sociedades ocidentais encontra correspondente ao que temos aqui, de sorte que só é possível identificá-los por meio de uma lista do que lhes falta, como escreveria Michel de Montaigne:

${ }^{37}$ Léry, op. cit., p. $231-232$.
${ }^{38}$ Léry, op. cit., p. 234.

Heródoto, Unifesp, Guarulhos, v. 3, n. 1, Março, 2018. p. 538-562 
Trata-se de uma nação, eu diria a Platão, na qual não há espécie alguma de tráfico [comércio], nenhum conhecimento das letras; nenhuma ciência dos números; nenhum magistrado, nem superioridade política; nenhum uso de trabalho [servidão], de riqueza ou de pobreza; não há contrato algum; nada de sucessões, nada de partilhas, há apenas ocupações ociosas; nenhum respeito de parentesco que não seja o comum, nenhuma vestimenta, nenhuma agricultura; nenhum metal, nenhum uso do vinho ou do trigo. As próprias palavras que significam mentira, traição, dissimulação, avareza, inveja, detração [maledicência], o perdão lhes são estranhas. ${ }^{39}$

Os ameríndios do Brasil representavam, portanto, a soma de tudo o que não somos e, mais precisamente, a negação do que considerávamos ser culto e civilizado. Nessas condições, como compreendê-los senão como seres não civilizados, quer dizer, selvagens? E, sobretudo, como abordá-los, senão através do filtro de nossas próprias convenções culturais?

Por isso os ameríndios causavam fascínio. No decorrer de todo século XVI, numerosos grupos de "selvagens da América" foram levados para a Europa. Desde 1509, sete ameríndios béothuks do Canadá desembarcaram na França com o navegador Thomas Aubert, que no ano anterior havia partido de Dieppe para uma viagem de pesca e de exploração ${ }^{40}$. Eram, sem dúvida, os primeiros "selvagens" do Novo Mundo, nunca antes vistos na França41. Enfeitados com plumas e com suas canoas de casca nas costas, eles desfilaram nas ruas de Rouen, onde causaram espanto. A exibição dos "selvagens" tornaria-se rapidamente um espetáculo. Em 1550, a cidade de Rouen acolheu uma extraordinária festa brasileira, organizada por ocasião da visita do rei Henrique II e de sua esposa Catarina de Médicis. Na parte exterior das fortificações, a floresta sempre verde do Brasil foi reconstituída, com árvores repletas de ramos de buxo nos quais foram suspensas réplicas de frutas magníficas da França Antártica. Ali, foram igualmente colocados animais da América, como macacos e papagaios. Uma trupe com mais de cem figurantes nus - dentre os quais estavam cerca de cinquenta autênticos índios Tupinambás - representava cenas da vida selvagem da "França Antártica". Os espectadores thes viam caçando animais, comercializando pau-brasil com os marinheiros franceses e, sobretudo, repelindo com bravura um ataque dos seus terríveis inimigos, os Tabajaras, que eram aliados dos portugueses. Diante do sucesso do espetáculo, duas outras festas com os "selvagens da América"

\footnotetext{
${ }^{39}$ Montaigne, Les Essais, Livre Ier, chapitre 31 (des cannibales), Paris 2002, éditions Arléa, p. 159.

40 Os Béothuks foram extintos no começo do século XIX, com a morte de Shanawdithit, o último representante conhecido desse grupo autóctone da Terra Nova.

41 Vicente Pinzon, que margeou as costas do Brasil em 1499, havia levado para Portugal um grupo de vinte ameríndios que sobrevivera à travessia. Pouco depois dele, Diego de Lepe levou para Sevilha escravos ameríndios, também de origem brasileira. Em 1501, Vespúcio havia levado três ameríndios do Brasil para Portugal, para que aprendessem a língua e pudessem ser intérpretes dos portugueses.
} 
seriam organizadas: uma em 1564, por ocasião da visita do rei Charles IX a Troyes, e, em seguida outra, em 1566, em Bordeaux ${ }^{42}$.

Como os macacos e os papagaios trazidos do Brasil, os pequenos "selvagens" eram distrubuídos como presentes. Em 1558, por acasião da volta de Lery à França, um grupo de dez jovens foi enviado ao rei Henrique II. 43 Eram escravos que haviam sido selecionados entre cerca de cinquenta prisioneiros de guerra, que Villegagnon havia comprado dos Tupinambás para trabalhar no Forte de Coligny. O monarca lhes distribuiria como presente real entre os senhores da corte. Alguns anos mais tarde, em 1562, em Rouen, Montaigne encontraria três ameríndios Tupinambás, que haviam vindo do Brasil e que seriam apresentados ao jovem rei Charles IX, que tinha mais ou menos 12 anos. A partir daquele extraordinário encontro Montaigne desenvolveria as reflexões contidas no seu célebre "Ensaio sobre os canibais". ${ }^{4}$

Ninguém sabe quantos foram os índios transportados do Brasil para a Europa como curiosidades exóticas, como escravos ou como visitantes e que nunca voltaram. Desembarcados na França, alguns indígenas do Novo Mundo fundariam famílias franco-ameríndias. Um dos primeiros, de quem hoje conhecemos um pouco da sua história, chamava-se Essomeriq. Esse jovem, filho de uma chefe ameríndio da costa do Brasil, embarcou em julho de 1504, com o capitão Binot Paulmier de Gonneville, à bordo do navio Espoir, que retornava ao seu porto: a comuna de Honfleur. Tendo quase morrido durante a travessia, Essomeriq foi batizado pelo capitão, que lhe deu o nome de Binot. De volta à Normandia, o capitão Gonneville o educou com seu próprio filho. Quando Binot completou 30 anos, seu pai adotivo o casou com sua filha Suzanne. Com a sua morte, o capitão lhe deixou todos os seus bens em testamento, com a condição que Binot continuasse a fazer uso do nome Gonneville e transmitisse as armas da família ${ }^{45}$. Alguns anos mais tarde, em 1529, seis ameríndios, que haviam sido abandonados pelos portugueses na Ilha de Santa Helena; eles foram recolhidos por um navio francês, que os deixou em Dieppe. A maior parte dos traços dessas pessoas foram rapidamente perdidos. No entanto, um dentre esses ameríndios Tupi estabeleceu-se em Dieppe e ali se casou. Pode-se supor que ele encontrou uma

\footnotetext{
42 Ferdinand Denis, Une fête brésilienne célébrée à Rouen en 1550. Paris 1850, J. Techener.

${ }^{43}$ Léry, op. cit., p. 353.

${ }^{44}$ Montaigne, op. cit., Livre Ier, chapitre 31 (des cannibales), p. 156-164.

45 Binot Paulmier de Gonneville, Le Voyage de Gonneville (1503-1505) et la découverte de la Normandie par les Indiens du Brésil. Paris 1995, éditions Chandeigne. A aventura de Essomeriq é igualmente relatada por Paul Gaffarel, Histoire du Brésil français au XVIe siècle. Paris 1878, Maisonneuve, p 30-54.
} 
atividade e adquiriu bens. Ele morreu em Dieppe, em 1569, após ter vivido quarenta anos nessa cidade ${ }^{46}$.

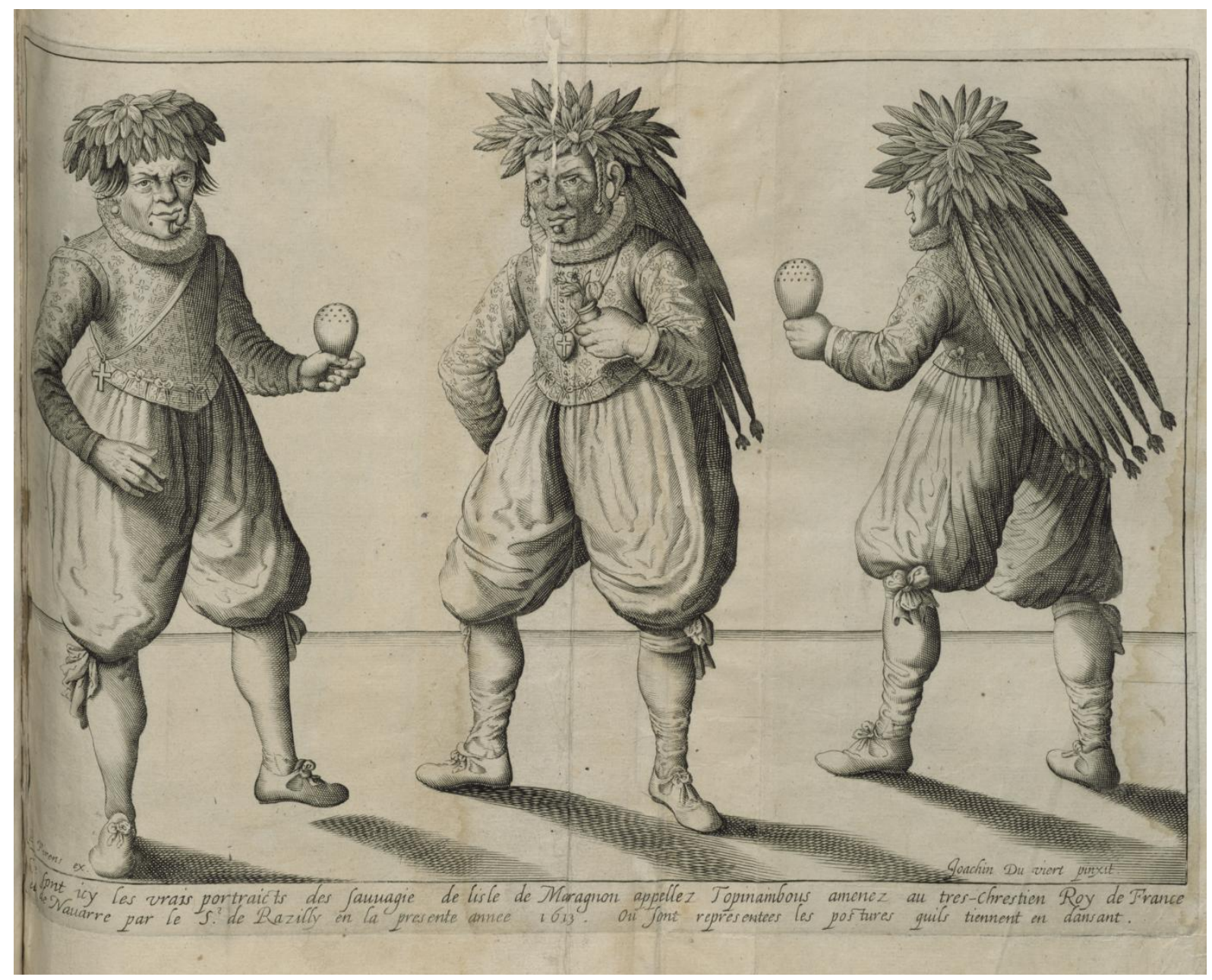

Fig. 4. Os tupinambá levados à França, Joachim du Viert e Pierre-Jean Mariette, 1613.

Em todos esses casos, não se tem a menor ideia do que esses ameríndios estabelecidos na França se tornaram em seguida. A chegada deles, ao descer do navio, não passava despercebida. Eles suscitavam a curiosidade da multidão, ainda mais quando ainda tinham um aspecto meio selvagem, restando uma margem suficiente para assimilá-los - vestindo-lhes como europeus, batizando-lhes ou casando-lhes (fig. 4). Mas, uma vez que isso fosse finalmente feito, o destino deles não interessava a mais ninguém. Eles não passam de estrangeiros dentre tantos outros, e nada mais era dito sobre eles. Seus filhos mestiços já não possuíam mais nada dos modos dos quais eles mesmo haviam sido despojados. Para que eles se integrassem, definitivamente, entre os europeus, era necessário esquecer de onde eram e de onde vinham.

${ }^{46}$ Afonso Arinos de Melo Franco, op. cit., p. 84. 


\section{"Nosso mundo acaba de encontrar um outro..."}

Desse passado hoje distante, restou-nos essas histórias que ainda hoje nos tocam, pois elas falam de um futuro impossível, que se estabelece no instante suspenso de um encontro que se entende como passageiro. Os universos dos "selvagens" e dos "civilizados" são inconciliáveis, e este confronto, em cuja inocência do encontro ainda se pode acreditar, assinala o fim de um mundo: os estrangeiros que aqui desembarcaram trazem consigo a depredação e a dominação que não tardariam a se instalar. Dizem que uma milagrosa conjunção foi produzida naquele momento, hoje tão distante de nós, e que, ao mesmo tempo, isso não poderia acontecer, pois já éramos, sem ainda o ser, o que nós tornaríamos. Fomos perturbados por esse encontro com os "selvagens" do Brasil, que durou apenas alguns anos, mas do qual ainda conservamos a surpresa, tal como Léry, ao retornar para a França com "uma estranha ferida no coração".

Pois o Outro é inacessível. Como tênues vestígios do passado, que se degradam quando os reatualizamos, não é possível abordar os "selvagens", tocá-los, sem ao mesmo tempo desfazê-los. Ao nosso contato, eles se dissolvem e "se desvanecem como um sonho", conforme já fora percebido por Plutarco com relação Gauleses, vencidos e colonizados pelos Romanos ${ }^{47}$. Esse mundo desaparecido tem, no entanto, a persistência fugitiva das imagens oníricas. Nós o vislumbramos, em um passado banido e doravante estranho, mas a sua presença invisível continua trabalhando secretamente no nosso presente. Nós a perdemos, mas restam impressões, soterradas nas profundezas da memória coletiva.

"Nosso mundo acaba de encontrar um outro"; foi assim que, nos anos 1580, Montaigne tomou nota nos seus Ensaios, da descoberta do Novo Mundo, para constatar que, mal o havíamos encontrado, nós já havíamos multilado e traído esse "mundo infantil" que se oferecia a nós"4. A tomada de posse das Américas é um extraordinário momento de confronto com o Outro, tal como o Ocidente nunca mais conhecera desde a Antiguidade. Pois, não se tratava de simples estrangeiros que encontravam viajantes vindos do outro lado do oceano, tratava-se de pessoas que ignoravam o que, aos olhos dos europeus, constituíam os fundamentos da humanidade e, ao mesmo tempo, de pessoas idênticas a eles, capazes de ter os mesmos sentimentos ${ }^{49}$. De modo que, essa

\footnotetext{
47 Plutarque, Vie de César, 27, 1-8.

48 Michel de Montaigne, Les Essais, Livre III, chapitre VI (des coches). Paris 2002, éditions Arléa, p. 658-662.

${ }^{49}$ Ton Lemaire, De Indiaan in on bewustsijn. De ontmeting van de Oude net de Nieuwe Wereld (The Indian in our Conciousness. The encounter between the Old and New World). Amsterdam 1986,
} 
descoberta dos "selvagens americanos" não apenas perturbou a ideia que nós [europeus] fazíamos do Outro, mas ela modificou igualmente, de forma profunda, o olhar que tínhamos de nós mesmos e arruínou a ficção da nossas origens fundamentais sobre a civilização. Seríamos apenas, em parte, herdeiros dos gregos e dos romanos, mais próximos desses "selvagens americanos" do que acreditávamos. Desse trágico confronto com o Outro, por intermédio do qual o Ocidente se apodera do Novo Mundo, nasce a consciência culpada de que o "selvagem" é tão humano quanto nós, assim como a inquietante suspeita de que nós mesmos fomos outrora, em um passado não tão distante, "selvagens" como eles. Nesse encontro com o Outro, constituiu-se também, de algum modo e de forma simétrica, o projeto de uma Antropologia que apreenderia a diferença e a proximidade do Outro e, por outro lado, o projeto de uma pré-história que acolheria a memória de nossas origens "selvagens" antes da civilização. Uma alimentando a outra com suas descobertas; tanto uma como a outra tentando escapar das amarras das tradições de pensamentos estabelecidos - de a prioris e de conformismos. $\mathrm{O}$ que, claro, é um sonho.

Os "selvagens" nus das Américas e os europeus que tomavam seus calções como um sinal distintivo de civilização há muito desapareceram. Isso tornouse história, ou arqueologia. Mas existe uma passagem por meio da qual é possível ir ao encontro desse momento encantador, no qual os encontramos pela primeira vez, "nesse encontro no qual mudamos, sem contudo nos perdermos e nos desnaturarmos", esse frágil e efêmero momento que é "também uma ocasião poética, na qual o ser mundano fazer crescer o ser interior", como Édouard Glissant e Patrick Chamoiseau escreveram. ${ }^{50}$ A arqueologia não cessa de mostrar, em toda parte, que nunca houve, em momento algum da história da humanidade, nem cultura "pura", nem identidade "em si". Os vestígios das civilizações do passado revelam apenas um emaranhado de identidades múltipas, que são incessantemente recompostas, uma interpolação de extratos culturais incessantemente recobertos, constantemente colocados em questão. Nós existimos apenas em relação; não há identidade fora da interferência de um Outro, que nos incomode e nos mude. Como igualmente escreveram Glissant e Chamoiseau:

De modo que todo conquistador é secretamente conquistado. Todo dominador é submerso pela alquimia da sua própria dominação. Tomar abre brechas a toda sorte de jugo. A força brutal e cega submete aquele que a exerce à fraquezas inevitáveis. Tomando o mundo, o Ocidente foi igualmente tomado por ele. ${ }^{51}$

éditions Ambo.

50 Edouard Glissant et Patrick Chamoiseau, Quand les murs tombent. L'identité nationale hors-laloi ? Paris 2007, éditions Galaade, Institut du Tout-Monde, p. 9-10.

${ }^{51}$ Glissant e Chamoiseau, op. cit., p. 14. 